Jurnal Pendidikan Jasmani Kesehatan dan Rekreasi (Penjaskesrek)

Volume 7, Nomor 2, Juli 2020

\title{
AKTIVITAS OUTBOND TERHADAP PENURUNAN TINGKAT KENAKALAAN SISWA SMA DAN SMK DI KECAMATAN ELLA HILIR
}

\author{
Eko Rudiansyah ${ }^{1}$, Rindah Permatasari ${ }^{2}$ \\ ${ }^{1}$ Dosen STKIP Melawi \\ ${ }^{2}$ Dosen STKIP Melawi \\ JL. RSUD Melawi Km. 04 Kec. Nanga Pinoh, Kab. Melawi Kalimantan Barat \\ Email: Ekorudiansyah90@gmail.com, Rindahpermatasari@gmail.com
}

\begin{abstract}
The ultimate goal of this is outbound activities as a way to reduce the delinquency level of SMA and SMK students in Ella Hilir District. This research uses a mixed method that combines two research methods at once, qualitative and quantitative in a research activity. The results of interviews with counseling guidance teachers and homeroom teachers at SMAS PGRI Ella Hilir and SMK Negeri 1 Ella Hilir explained that in general or all students decreased aggressive behavior. The results of the researchers' observations showed that the proportion of the initial conditions showed that from the total number of students who had a high level of delinquency, 54.09\% of PGRI Ella Hilir High School students were classified as high and 64.04\% of Ella Hilir State Vocational School students were classified as very high, while the final conditions of PGRI Ella Hilir High School students $1842 \%$ are classified as very low and students of SMK Negeri Ella Hilir 19.30\% are classified as very low. The results of the statement analysis showed that there was a decrease in the level of delinquency of SMA and SMK students in the Ella Hilir sub-district. The decrease is indicated by the significant value of the Wilcoxon Sign Rank Test results which is smaller than the significant level $(\alpha)$, namely $0.000<0.05$.
\end{abstract}

Keywords: Outbond, decline, delinquency

\begin{abstract}
Abstrak
Tujuan akhir dari penulisan ini adalah aktivitas outbond sebagai salah satu cara untuk menurunkan tingkat kenakalaan siswa SMA dan SMK di Kecamatan Ella Hilir. Penelitian ini menggunakan mix methods yang mengkombinasikan antara dua metode penelitian sekaligus, kualitatif dan kuantitatif dalam suatu kegiatan penelitian.Hasil wawancara dengan guru bimbingan konseling dan guru wali kelas SMAS PGRI Ella Hilir dan SMK Negeri 1 Ella Hilir menjelaskan bahwa secara umum atau kebanyakan siswa perilaku agresif menurun. Hasil data observasi peneliti menunjukan persentase kondisi awal menunjukan dari jumlah keseluruhan siswa yang memiliki yaitu tingkat kenakalan siswa SMAS PGRI Ella Hilir 54,09\% tergolong tinggi dan siswa SMK Negeri Ella Hilir 64,04\% tergolong sangat tinggi, sedangakaan kondisi akhir siswa SMAS PGRI Ella Hilir 18,42\% tergolong sangat rendah dan siswa SMK Negeri Ella Hilir 19.30\% tergolong sangat rendah. Hasil analisis menyatakan bahwa terdapat penurunan tingkat kenakalan siswa SMA dan SMK di kecamatan Ella Hilir. Penurunan ditunjukkan oleh nilai signifikan hasil Wilcoxon Sign Rank Test lebih kecil dibanding taraf signifikan (a) yaitu $0,000<0,05$
\end{abstract}

Kata Kunci: Outbond, Penurunan, Kenakalaan

64 | JPJKR, p-ISSN: $2252-8148$, e - I S S N : $2579-4604$ 
Deran sekolah dalam membentuk
perilaku siswa yang baik dan positif adalah dengan upaya-upaya seperti persuasif, preventif, maupun kuartif, termasuk mengikuti aktivitas Outbond. Upaya-upaya tersebut sangatlah diperlukan dalam pola pembentukan perilaku siswa yang ideal, sehingga perilaku yang kurang baik seperti kenakalan maupun perilaku agresif dapat terkendali. Pemberian dukungan bagi terciptanya perilaku yang tidak menyimpang, mendorong siswa untuk berperilaku positif dan produktif serta membantu siswa untuk dapat memahami dan menyesuaikan diri dengan tuntunan lingkungan sekolah, sehingga siswa tersebut bisa belajar hidup dengan kebiasaankebiasaan yang baik.

Kenakalan seperti disekolah sering terjadi dikalangan siswa SMA dan SMK, dikarenakan siswa masih tergolong remaja, kerap sekali sulit mengikuti proses perkembangan, baik itu dari perubahan fisik, emosi, mental dan sosial, pengaruh lingkungan sangat berperan dalam pembentukan sikap dan perilaku remaja. Kenakalan terjadi pada siswa SMA dan SMK dikarenakan perilaku yang agresif, perilaku tersebut berbentuk verbal dan non verbal yaitu penggunaan kata-kata kasar, mengejek, berkelahi, pemerasan, kebutkebutan dijalan, membolos sekolah, merokok, merusak fasilitas umum (Wibowo, 2005:241).

Berdasarkan dari hasil wawancara dengan guru SMA salah satu SMA yang ada di kecamatan Ella Hilir bahwa siswa yang memiliki catatan kenakalan diwujudkan dalam bentuk perilaku agresif verbal dan non verbal, yaitu verbal berupa saling mengejek, berkata kasar, mengancam perkataan dengan teman dan membantah perkataan dengan guru di sekolah, serta perilaku agresif non verbal yaitu merokok, memukul dan membolos sekolah. Tindakan yang diberikan hanyalah sebatas teguran dan hukuman

Pembelajaraan yang dilakukan selama ini hanyalah sebatas pada pengembangan intektual. Terbatasnya aktivitas olahara dan outbond yang dilakukan siswa, sehingga emosi yang tersalurkan tidak menuju ke hal yang positif. Aktivitas outbond berkaitan dengan perasaan nyaman dan bugar serta keharmonisan kepribadian seseorang. Aktivitas Outbond merupakan suatu bentuk dari pembelajaraan segala ilmu terapan atau tertutup dengan bentuk permainan yang efektif yang menggabungkan antara 
intlegensia, fisik dan mental. Melakukan aktivitas Outbond secara teratur dan memiliki unsur permainan dan kerja sama tim, akan memiliki manfaat ilmu yang disisipkan dalam permainan Outbond, lebih mengenal lingkungan serta membangun percaya diri.

Permasalahaan yang akan diteliti adalah sebagai berikut deskripsi kenakalan, dan pengaruh aktivitas outbond terhadap penurunan tingkat kenakalan siswa SMA dan SMK di Kecamatan Ella Hilir Kabupaten Melawi. Tujuan akhir dari Penulisan ini adalah aktivitas outbond sebaga salah satu cara untuk menurunkan tingkat kenakalaan siswa SMA dan SMK di Kecamatan Ella Hilir.

Menurut Kartono (2014: 6) kenakalan merupakan perilaku jahat (dursila), atau kejahatan atau kenakalan anak-anak muda, merupakan gejala sakit patalogis secara sosial pada anak-anak dan remaja yang disebabkan oleh satu bentuk pengabaian sosial, sehingga mereka itu mengembangkan bentuk tingkah laku yang menyimpang.

Menurut Shoemaker (2010) dalam jurnal yang berjudul Family Instability and Juvenile Delinquency in Negeria: A Study of Owerri Municipality, menarik simpulan sebagai berikut:
"Didefinisikan sebagai tindakan tidak diinginkan dari kenakalan remaja, apakah status atau tindak pidana, yang dilakukan oleh remaja di bawah usia 18. Dari definisi ini, itu adalah relevan untuk menyoroti dua jenis pelanggaran kejahatan yang terkait dengan anak muda. Jenis pertama dari pelanggaran adalah perilaku yang akan menjadi pelanggaran hukum pidana untuk orang dewasa, seperti pencurian, perampokan, dan pemerkosaan."

Menurut Kartono (2014:8) bahwa kenakalan ini disebut sebagai salah satu penyakit masyarakat atau penyakit sosial. Penyakit sosial atau penyakit masyarakat adalah segala bentuk tingkah laku yang dianggap tidak sesuai, dengan norma-norma umum, adat istiadat, hukum formal atau tidak dapat diintegrasikan dalam pola tingkah laku umum.

Dapat disimpulkan bahwa perilaku tersebut sebagai salah satu penyakit masyarakat atau penyakit sosial. Dan tindakan yang dilakukan remaja diluar kebiasaan, adat istiadat, aturan, nilai-nilai atau norma sosial yang berlaku.

Dapat disimpulkan berdasarkan pada penjelasan diatas, bahwa dalam kondis statis, gejala juvenile delinquency atau kejahatan remaja merupakan gejala sosial yang sebagian dapat diamati serta diukur 
kuantitas, namun sebagian lagi tidak bisa diamati dan tetap tersembunyi, hanya bisa dirasakan. Sedang dalam kondisi dinamis, gejala kenakalan remaja tersebut merupakan gejala yang terus-menerus berkembang, berlangsung secara progresif sejajar dengan perkembangan teknologi, indsutrialisasi dan urbanisasi.

Tandiyo dan Eunike (2012:11) menjelaskan bahwa kecerdasan emosi berkaitan dengan tingkat emosional yang dapat ditingkatkan dengan melibatkan banyak area otak. Kecerdasan emosi mampu memprediksi seluruh kesuksesan dalam kehidupan, karena mampu mengatur perilakunya sendiri dan perilaku orang lain. Kecerdasan emosi mampu berinteraksi dengan orang lain, dan baik untuk mengelola hubungan dengan orang lain.

Nurhasan (2004: 1-3) menyebutkan total fitnes diantaranya psychological fitnes adalah keadaan seseorang yang menggambarakan mengenai stabilitas emosi yang berguna dalam mengatasi masalahmasalah setiap hari dari lingkungannya, dan kemampuan untuk mengatasi gangguan emosi yang timbul secara mendadak, seperti berita duka yang mampu menyakitkan hati.

Ngalim Purwanto (2010:170) menjelaskan bahwa faktor dari dalam diri siswa yang mendukung prestasi siswa dalam aspek psikologis salah satunya adalah kecerdasan. Surya Narpati Awangga (2008:19) mengatakan bahwa kecerdasan emosional merupakan kemampuan seseorang untuk memotivasi diri sendiri, bertahan menghadapi frustasi, mengendalikan dorongan hati dan tidak melebih-lebihkan kesenangan, mengatur susana hati serta mampu mengelola suatu komunitas.

Outbond adalah kegiatan di alam terbuka. Outbond juga dapat memacu semangat belajar. Outbond merupakan sarana penambah wawasan pengetahuan yang didapat dari serangkaian pengalaman berpetualang sehingga dapat memacu semangat dan kreativitas seseorang. Oleh karena itu, Kimpraswil menyatakan bahwa outbound adalah usaha olah diri (olah pikir dan olah fisik) yang sangat bermanfaat bagi peningkatan dan pengembangan motivasi, kinerja dan prestasi dalam rangka melaksanakan tugas dan kepentingan organisasi secara lebih baik lagi.

Outbound adalah suatu bentuk dari pembelajaran segala ilmu terapan yang disulasikan dan dilakukan di alam terbuka atau tertutup dengan bentuk permainan yang efektif, yang menggabungkan antara intelegensia, fisik dan mental. Outbound merupakan inovatif yang ditemukan oleh 
cendikiawan berkebangsaan Jerman yang bernama Dr. Kurt Hant. Beliau lahir di Jerman pada tanggal 5 Juni 1886. Ilmu dan ide terapan pendidikan inovatif outbound Kurt Hant bertahan dan berkembang sampai saat ini. Sekarang semua kegiatan outbound di sesuaikan dengan kebutuhan untuk mencapai tujuan yang di target.

Kegiatan outbound berawal dari sebuah pengalaman sederhana seperti bermain. Bermain juga membuat setiap anak merasa senang, dan bahagia. Dengan bermain anak dapat belajar menggali dan mengembangkan potensi, dan rasa ingin tahu serta meningkatkan rasa percaya dirinya. Oleh karena itu, bermain merupakan fitrah yang dialami setiap anak.

Kegiatan belajar di alam terbuka seperti outbound bermanfaat untuk meningkatkan keberanian dalam bertindak maupun berpendapat.

Kegiatanoutbound membentuk pola pikir yang kreatif, serta meningkatkan kecerdasan emosional dan spiritual dalam berinteraksi. Kegiatan ini akan menambah pengalaman hidup seseorang menuju sebuah pendewasaan diri.

Outbound merupakan metode pengembangan diri yang menarik dan menyenangkan. Mengapa demikian, Bagi setiap instansi yang melakukan kegiatan outbound pastinya memiliki tujuan masingmasing. Pada umumnya tujuan outbound sebagai terapi bagi peserta yang tidak punya kemampuan banyak bicara, minder, dan kurang percaya diri. Outbound sendiri selalu mengedepankan permainan-permainan yang mampu menumbuhkan motivasi pada diri pesertanya. Biasanya pola permainan yang diadakan melibatkan kerja sama antar team ataupun masing-masing individu itu sendiri guna melatih pikiran dan aktivitas fisik yang memiliki nilai positif. Tidak bisa di pungkiri bahwa outbound adalah pilihan tepat bagi semua kalangan dalam pengembangan diri yang fun dan menarik serta menyenangkan. Sedangkan tujuan penerapan metode outbound dalam pembelajaran ini sendiri adalah membentuk kelompok dalam permainan yang bisa memberikan peserta sebuah pengalaman baru.

Kegiatan outbound di alam terbuka bermanfaat untuk meningkatkan keberanian dalam bertindak maupun berpendapat. Kegiatan outbound membentuk pola pikir yang kreatif, serta meningkatkan kecerdasan emosional dan spiritual dalam berinteraksi. Kegiatan ini akan menambah pengalaman hidup seseorang menuju sebuah pendewasaan diri.

Penelitian yang dilakukan Ugwuoke, C.U. \& Duruji, Onyekachi (2015) dengan 
judul ketidak stabilan keluarga dan kenakalan remaja di Nigeria: sebuah studi Owerri kotamadya. Hasil analisis menunjukkan bahwa anak-anak dari rumah yang tidak stabil lebih terlibat dalam kenakalan remaja daripada rekan-rekan mereka dari rumah-rumah yang lebih stabil. Seperti yang diharapkan, pengawasan orangtua tidak cukup memprediksi kenakalan.

Penelitian yang dilakukan Lolang Mariana (2014:114) Pengembangan Model Bimbingan Kelompok Dengan Teknik Outbound Untuk Mengurangi Perilaku Agresif Siswa Smk Swasta Kota Semarang. Hasil uji coba lapangan menunjukan tingkat perilaku agresif siswa mengalami penurunan. Tingkat perilaku agresif siswa sebelum bimbingan kelompok adalah 67,88\% dan setelah bimbingan kelompok menurun menjadi 46,93\%. Terjadi penurunan sebesar $20,94 \%$.

\section{METODE}

Penelitian ini adalah penelitian mix methods. Menurut Sugiyono (2013:345) mix methods adalah metode penelitian dengan mengkombinasikan antara dua metode penelitian sekaligus, kualitatif dan kuantitatif dalam suatu kegiatan penelitian, sehingga akan diperoleh data yang lebih komprehensif, valid, reliabel, dan objektif. Desain penelitian yang digunakan adalah single case experimental designyaitu sebuah desain penelitan untuk mengevaluasi efek suatu perlakuan dengan kasus tunggal dan melakukan pengukuran yang sama dan berulang-ulang untuk mempelajarai seberapa banyak perubahan yang terjadi dari hari ke hari, dengan gambaran umum perilaku (Barlow Nock \& Hersen 2009).

Pelaksanaan sebelum perlakuan pretest, penelti terlebih dahulu mengetahui informasi tentang kenakalan, kecerdasan emosional dan aktivitas Outbond pada siswa SMA dan SMK, dilanjutkan dengan memberikan perlakuan aktivitas Outbond permainan dan diakhiri dengan posttest

Penelitian ini difokuskan pada kenakalan siswa, kecerdasan emosional, dan aktivitas Outbond. Serta siswa SMAS PGRI Ella Hilir kelas X dan siswa SMK Negeri 1 Ella Hilir kelas $\mathrm{X}$, dengan jumlah siswa keseluruhan 56 siswa, yang memiliki catatan kenakalan. Fokus penelitian kemudian menjadi rumusan masalah yang dijawab penulis melalui penelitian yang telah dilakukan. Pengamatan di lapangan dan pengumpulan data dilakukan oleh peneliti sesuai dengan wawancara, Observasi dan penyebaran angket telah dibuat sesuai dengan fokus penelitian.Peneliti mengikuti 
fokus penelitian.Fokus penelitian menjadi acuan peneliti saat penelitian di lapangan, sehingga penulis memperoleh hasil yang mendalam dan tidak meluas.

\section{HASIL DAN PEMBAHASAAN}

Berdasarkan hasil wawancara kondisi awal (Pretest) dengan guru bimbingan konseling, kepala sekolah dan guru penjaskesrek catatan kenakalan diwujudkan dalam bentuk perilaku agresif verbal seperti tindakan tidak displin masuk terlambat, melawan perintah guru, serta agresif non verbal yaitu merokok, membolos sekolah.

Perilaku agresif pada siswa dikatagorikan agresif rendah, agresif sedang, agresif tinggi. Bentuk agresif rendah yaitu berkata kasar ketika emosi, bercanda yang berlebihan sehigga terjadinya saling mengejek satu sama lainnya, adapun bentuk agresif sedang pada siswa sering dating terlambat bahkan telambatnya lebih dari 15 menit, membolos pada saat pergantian jam mata pelajaran yang lain, melawan guru dengan membalas ucapan dengan nada emosi, dan berpakaian tidak rapi. sedangkan perliaku agresif tinggi yang dilakukan siswa yaitu merokok pada jam di sekolah, pada saat pulang sekolah merokok di warung dengan teman-teman.

Berdasarkan hasil observasi di lapangan, peneliti mendapatkan hasil yang berbeda dari data yang didapatkan dari guru bimbingan konseling, hasil data observasi peneliti menunjukan persentase kondisi awal perilaku agresif rendah, agresif sedang, dan agresif tinggi menunjukan jumlah keseluruhanya yaitu tingkat kenakalan siswa SMAS PGRI Ella Hilir 54,09\% tergolong tinggi dan siswa SMK Negeri Ella Hilir $64,04 \%$ tergolong sangat tinggi. Adapun kondisi awal dari hasil observasi kenakalan siswa SMA dan SMK di Kecamatan Ella Hilir Kabupaten Melawi adalah sebagai berikut:

Tabel 1 Hasil Observasi Kondisi Awal (Pretest) Kenakalan

Siswa SMA dan SMK

\begin{tabular}{ccccc}
\hline N & Nama Sekolah & $\begin{array}{c}\text { Jumlah } \\
\text { Rata-Rata }\end{array}$ & Keterangan Tingkatan & Secar \\
\cline { 1 - 3 } 1 & SMAS PGRI Ella Hilir & $54.09 \%$ & Tinggi & $\mathrm{a}$ \\
\cline { 1 - 3 } 2 & SMK Negeri 1 Ella Hilir & $64,04 \%$ & Sangat Tinggi & $\mathrm{m}$ \\
\hline
\end{tabular}

siswa SMA dan SMK yang memiliki catatan 
kenakalan disebabkan dari faktor eksternal dan internal. Faktor eksternal yaitu pergaulan dengan teman yang memiliki catatan kenakalan, lingkungan tempat tinggal yang memang kasar, dan kurangnya perhatian dari orang tua. Kepedulian orang tua masih sangat kurang dengan kesibukan orang tua sampai siswa tidak terpantau sehingga siswa memiliki pergaulan yang kurang baik dan bahkan adapun siswa yang diasuh dengan nenek atau kakeknya, dan anak bebas melakukan sesuka mereka. Adapun faktor internalnya yaitu siswa kurang membentengi dirinya ketika diajak teman membolos bahkan merokok mudah terpengaruh, dan juga siswa kurang dalam mengontrol emosinya.

Berdasarkan hasil wawancara Kenakalan yang terjadi pada siswa SMAS PGRI Ella Hilir dan SMK Negeri 1 Ella Hilir diwujudkan dalam bentuk perilaku agresif verbal dan non verbal, yaitu perilaku agresif verbal berupa bercanda yang berlebihanan (saling mengejek), berkata kasar, dengan teman dan membantah perkataan dengan guru di sekolah, sedangkan perilaku agresif non verbal yaitu merokok, dan membolos sekolah.

Dari hasil wawancara dan observasi SMA dan SMK di Kecamatan Ella Hilir menunjukan adanya perbedaan pada kondisi awal (pretest) dan kondisi akhir (postest) yaitu pada kondisi awal (pretes) tingkat kenakalan siswa masih tergolong sangat tinggi, seperti siswa masih perilaku agresif verbal berupa saling mengejek, berkata kasar, mengancam perkataan dengan teman dan membantah perkataan dengan guru di sekolah, serta agresif non verbal yaitu merokok, memukul dan membolos sekolah. Sedangkan pada kondisi akhir (postest) dari hasil wawancara dengan guru bimbingan konseling dan guru wali kelas SMAS PGRI Ella Hilir dan SMK Negeri 1 Ella Hilir menjelaskan bahwa secara umum atau kebanyakan siswa perilaku agresif menurun, Namun secara individu perilaku agresif yang ada pada siswa tidak seluruhnya menurun, masih ada siswa melakukan perilaku agresif rendah. Hal tersebut disebabkan dari faktor eksternal yaitu pergaulan negatif, lingkungan tempat tinggal kasar, dan perhatian orang tua yang kurang, sedangkan faktor internalnya sulitnya siswa dalam mengelola emosi.

Berdasarkan hasil observasi di lapangan yang termuat pada Tabel 1 menunjukan persentase kondisi awal dari jumlah keseluruhan siswa yang memiliki yaitu tingkat kenakalan siswa SMAS PGRI Ella Hilir 54,09\% tergolong tinggi dan siswa SMK Negeri Ella Hilir 64,04\% tergolong 
sangat tinggi, sedangkan setelah diberikan treatment menunjukan jumlah keseluruhanya yaitu tingkat kenakalan siswa SMAS PGRI Ella Hilir 18,42\% tergolong sangat rendah dan siswa SMK Negeri Ella Hilir $19.30 \%$ tergolong sangat rendah.

Tabel 2.Jumlah Rata-Rata Data Observasi Kondisi Awal dan Kondisi Akhir

\begin{tabular}{cccccc}
\hline No & Nama Sekolah & $\begin{array}{c}\text { Kondisi } \\
\text { Awal }\end{array}$ & $\begin{array}{c}\text { Keterangan } \\
\text { Tingkatan }\end{array}$ & $\begin{array}{c}\text { Kondisi } \\
\text { Akhir }\end{array}$ & $\begin{array}{c}\text { Keterangan } \\
\text { Tingkatan }\end{array}$ \\
\hline 1 & SMAS PGRI Ella Hilir & $54.09 \%$ & Tinggi & $18,42 \%$ & Sangat Rendah \\
\hline 2 & SMK Negeri 1 Ella Hilir & $64,04 \%$ & Sangat Tinggi & $19.30 \%$ & Sangat Rendah \\
\hline
\end{tabular}

Adanya penurunan tingkat berubah menjadi sangat rendah pada kondisi kenakalaan setelah diberikan aktivitas akhir.

Outbond. Dari kondisi awal SMAS PGRI Ella Hilir tingkatan kenakalaan Tinggi sedangakan kondisi akhir tingkatakan kenakalaan sangat rendah. SMK Negeri 1 data awal tingkatan kenakalan Sangat tinggi
Data diatas juga didukung dengan data adanya perubahan tingkat kecerdasaan emosional dengan hasil adalah Sebagai berikut

Tabel 3. Statistik deskriptif Kecerdasaan Emosional SMA dan SMK di Kecamatan Ella Hilir

\begin{tabular}{lccccc}
\hline & N & Minimum & Maximum & Mean & Std Deviation \\
\hline Pretest & 37 & 116 & 155 & 129.03 & 11.006 \\
\hline Posttest & 37 & 119 & 165 & 145.86 & 10.662 \\
\hline Valid N (listwise) & 37 & & & & \\
\hline
\end{tabular}


Tabel 4. Uji Normalitas Kecerdasaan Emosional SMA dan SMK di Kecamatan Ella Hilir

\begin{tabular}{lcccccc} 
& \multicolumn{3}{c}{ Kolmogorov-Smirnov $^{\mathrm{a}}$} & \multicolumn{3}{c}{ Shapiro-Wilk } \\
\cline { 2 - 7 } & Statistic & Df & Sig & Statistic & Df & Sig. \\
\hline Pretest & .330 & 37 & .000 & .773 & 37 & .001 \\
\hline Posttest & .124 & 37 & .264 & .977 & 37 & .632 \\
\hline
\end{tabular}

Nilai taraf signifikan $(\alpha)$ yang digunakan $=$ $5 \%=0,05$. Sample berjumlah 37 peserta didik sehingga uji normalitas menggunakan Shapiro Wilk. Hasil analisis normalitas pretest menunjukkan nilai signifikan $<\alpha$ yaitu $0,000<0,05$ yang menunjukkan bahwa data tidak berdistribusi normal. Hasil analisis normalitas posttest menunjukkan nilai signifikan $>\alpha$ yaitu $\quad 0,632>0,05$ yang menunjukkan bahwa data berdistribusi normal. Salah satu data tidak berdistribusi normal, maka analisis selanjutnya menggunakan uji nonparametrik.

Tabel 5. Uji Wilcoxon Signed Rank Test Kecerdasaan Emosional SMA dan SMK di Kecamatan Ella Hilir

\begin{tabular}{lllll}
\hline \multicolumn{2}{c}{ Null Hypothesis } & \multicolumn{1}{c}{ Test } & Sig. & \multicolumn{1}{c}{ Decision } \\
\hline $\mathbf{1}$ & The median of differences & Related-Samples & .000 & Reject the null \\
between pretest and & Wilcoxon Signed & & hypothesis \\
posttest equqls 0. & Rank Test & & \\
\hline
\end{tabular}

Kriteria nilai $\operatorname{sig}<\alpha=0,000<0,05$ maka Ho ditolak. Menggunakan $\alpha=5 \%$ dapat disimpulkan bahwa bahwa terjadi penurunan kenakalan pada siswa SMA dan SMK kecamatan Ella Hilir.

Peran sekolah dalam membentuk perilaku siswa yang baik dan positif adalah dengan upaya-upaya seperti persuasif, preventif, maupun kuartif, termasuk mengikuti aktivitas olahraga.Upaya-upaya tersebut sangatlah diperlukan dalam pola pembentukan perilaku siswa yang ideal, sehingga perilaku yang kurang baik seperti kenakalan maupun agresif dapat terkendali.Pemberian dukungan bagi terciptanya perilaku yang tidak menyimpang, mendorong siswa untuk berperilaku positif dan produktif serta membantu siswa untuk dapat memahami dan menyesuaikan diri dengan tuntunan 
lingkungan sekolah, sehingga siswa tersebut bisa belajar hidup dengan kebiasaankebiasaan yang baik

Berdasarkan permasalahan pada siswa SMA dan SMK di Kecamatan Ella Hilir, peneliti memberikan solusi terkait aktivitas Outbond di sekolah dan kenakalan siswa, dengan tujuan menarik minat siswa untuk terlibat dalam aktivitas Outbond, untuk menyalurkan emosi yang ada pada siswa kearah yang positif, dan menurunkan tingkat kenakalan ataupun perilaku agresif pada siswa. Setelah diberikanya perlakuan aktivitas olahraga permainan, secara umum dan diambil rata-ratanya dari seluruh siswa, menunjukan adanya penurunantingkat kenakalan siswa. Telah diketahui bahwa setelah meningkatnya kecerdasan emosional berpengaruh terhadap penurunan tingkat kenakalan siswa, atau dengan kata lain bahwa hipotesis penelitian yang diajukan terbukti kebenaranya. Berdasarkan data yang diuraikan diatas Setelah diberikan aktivitas Outbond bahwa terdapat penurunan dari tingkatan kenakalaan siswa SMA dan SMK di kecamataan Ella Hilir.

\section{SIMPULAN DAN SARAN}

Simpulan dari penelitian ini menyatakan bahwa 1) kenakalaan yang terjadi di SMA dan SMK di Kecamatan Ella Hilir tergolong masih tinggi, adapun kenakalaan yang sering dilakukan siswa adalah seperti bolos sekolah, merokok dikantin, bersikap kasar kepada sesame teman dan berkata kasar kepada guru. 2) Kecerdasaan emosional merupakan kunci keberhasilan hidup seseorang, tentunya kecerdesaan emosional juga bagian dari kenakalan siswa, dari hasil data empiris dilapangan menyatakan terdapat perubahan penuruan tingkat kenakalaan setelah diberikan aktivitas outbond di SMA dan SMK Kecamatan Ella hilir.

Mengatasi permasalahan kenakalan terhadap siswa di SMA dan SMK di Kecamatan Ella Hilir guru penjaskesrek dan guru bimbingan konseling bersama-sama memberikan solusi untuk mengatasi kenakalaan yang terjadi. Melalui penerapan aktivitas outbond pada siswa SMA dan SMK di Kecamatan Ella Hilir, diharapkan bisa diterapkan sebagai kegiatan olahraga di sekolah dan sebagai solusi untuk mengatasi siswa yang memiliki tingkat kenakalan tinggi dan meningkatkan kecerdasan emosional siswa.

\section{DAFTAR PUSTAKA}

Aviyah, E., \& Farid, M. (2014). Religiusitas, kontrol diri dan kenakalan remaja.Persona: Jurnal Psikologi Indonesia, 3(02). 
Barlow, D. H., Nock, M. K. and Hersen, M. (2009). Single-case experimental designs:Strategies for studying behavior change (3rd edn). New York: Pearson.

Kartono, K. 2014. Kenakalan Remaja. Depok: PT Rajagrafindo Persada.

Mariana, L. 2014. Pengembangan Model Bimbingan Kelompok Dengan Teknik Outbound Untuk Mengurangi Perilaku Agresif Siswa Smk Swasta Kota Semarang. Semarang. Jurnal Bimbingan Konseling Universitas Negeri Semarang. 3 (2) 112-117.

Nindya, P. N., \& Margaretha, R. (2012). Hubungan antara kekerasan emosional pada anak terhadap kecenderungan kenakalan remaja. Jurnal Psikologi Klinis dan Kesehatan Mental, 1(02), 1-9.

Shoemaker, D. 2010. Theories Of Delinquency. New York. Oxford University Press.
Sugiyono. 2013. Cara Mudah Menyusun Skripsi, Tesis, dan Desertasi. Yogyakarta: CV. Alfabeta.

Pramesti Getut.2014. Kupa Tuntas Data Penelitiaan dengan SPSS 22. PT Elex Media Komputindo, Jakarta

Tandiyo \& Eunike. 2012. Pengembangan Kecerdasan Emosi Siswa Sekolah Dasar Melalui Pendidikan Jasmani. Semarang: Cipta Prima Nusantara.

Ugwuoke, C. U. \& Durji Onyekachi U. 2015.Family Instability and Juvenile Delinquency in Nigeria: A Study of Owerri Municipality. Nigeria. Journal Of Humanities and Social Sicience. 1 (20) 40-44

Umar, T. (2011). Pengaruh Outbond Training terhadap Peningkatan Rasa Percaya Diri Kepemimpinan dan Kerjasama Tim. Ilmiah SPIRIT, 11(3).

Wibowo, mungin. 2005. Konseling kelompok perkombengan. Semarang:UNNES PRESS. 